\title{
Re-Corrosion in Simulated Refurbished Patches of Corroded Lightweight Reinforced Concrete Structures
}

\author{
Muhammad Wasim*1 and Raja Rizwan Hussain ${ }^{2}$ \\ ${ }^{1}$ Department of Civil Environmental and Chemical Engineering, RMIT University, Australia \\ ${ }^{2}$ Associate Professor, Civil Engineering department, King Saud University, Saudi Arabia
}

Submission: June 02, 2018; Published: July 13, 2018

*Corresponding author: Muhammad Wasim, Department of Civil Environmental and Chemical Engineering, RMIT University, Melbourne Australia, Email: mwasim@unimelb.edu.au; s3442859@student.rmit.edu.au

\begin{abstract}
This paper presents experimental investigation on the corrosion behavior in the repaired corroded patches of self-compacting and lightweight reinforced concrete structures. This research is a continuation of previous studies in which authors observed corrosion in the repaired corroded patches of ordinary concrete (OC) in the form of macro-cell. In the current this phenomenon is investigated in lightweight concrete (LWC) and compared with self-compacting concrete (SSC) by long term experiments. It is reviewed that for modern construction, LWC is gaining attention among civil engineers for ordinary and offshore structures construction due to its lightweight and workability over OC. However, the question whether the corrosion behavior in the normal and repaired patches of LWC is the same like other types of concrete is still remained to be answered. This paper addresses this question and evaluates the performance of the corroded repair patches of LWC structure in highly corrosive environments. Test specimens were prepared with LWC closely simulating field conditions in such a way that their two ends were contaminated with $5 \%$ and $3 \%$ chloride respectively and the middle portion (simulated repaired patch) was cast after one day with LWC having no chloride in it. After 180 days of electrochemical and physical corrosion measurements of specimens, re-corrosion phenomenon in the repaired patches was observed. This research has practical application and it can be used for developing models for the predictions of service and remaining service of LWC structures in corrosive environments.
\end{abstract}

Keywords: Lightweight aggregate concrete; Chloride content; Reinforcing steel; Macro-cell; Patch repair

Abbrevations: LWC: Light weight concrete; SSC: Self-Compacting Concrete; OC: Ordinary Concrete

\section{Introduction}

Light weight concrete (LWC) construction is getting popular in modern construction industries now-a-days [1-4]. LWC construction is environmental friendly and it is cost effective as compared to normal type of concrete [5,6]. There are many sources of lightweight aggregate including natural aggregate such as scoria, pumice, scoria and obtained from volcanic origin, and the manufactured aggregate such as silica fume, blastfurnace slag, clinker and vermiculite [7]. Lightweight aggregates are reported to be manufactured from fly ash [7]. Moreover, it is reported that high strength lightweight concrete was developed by combining silica fume and/or fly ash with lightweight aggregate for structural applications [8].

Structural deterioration of marine structures due to corrosion is one of the major concerns for asset managers and owners. Structural patch repair is the most commonly applied practice in the construction and repair industry though such repairs are found vulnerable [9]. Authors of this paper have previously investigated re-corrosion phenomenon in the repaired concrete patches of the reinforced OC and SSC [10-12]. The question whether this phenomenon occurs in LWC and the comparison of corrosion behavior between SCC and LWC are the main objectives of this paper.

\section{Experimental Methodology}

Table 1: Mix proportion for the lightweight concrete.

\begin{tabular}{|c|c|}
\hline Materials & $\mathbf{K g} / \mathbf{m}^{\mathbf{3}}$ \\
\hline Cement content & 380 \\
\hline Silica fume & 20 \\
\hline Light weight coarse aggregates & 548 \\
\hline Light weight Fine aggregates & 348.7 \\
\hline Red silica sand & 199.9 \\
\hline Water & 249.1 \\
\hline Super plasticizer (L) & 3 \\
\hline
\end{tabular}




\section{Civil Engineering Research Journal}

For the preparation of the LWC mix, natural volcanic rock stones after cursing to a size of $20 \mathrm{~mm}$ were used as coarse aggregate with density of $1.94 \mathrm{~g} / \mathrm{cm}^{3}$. OPC Type 1 cement, and sand of $4.75 \mathrm{~mm}$ IS sieve was used having density and water absorption of $2.65 \mathrm{~g} / \mathrm{cm}^{3}$ and $0.38 \%$, respectively. Super plasticizer selected for achieving high workability of the mix was conplast SP 430 with main ingredient of polycarboxylic. The more details of the mix design of LWC can be found elsewhere [7]. The mix proportion used in this investigation for LWC specimens is shown in Table 1, while, the mix proportion and preparation for SCC specimens can be found somewhere else
[12]. For reinforcement, carbon steel bars of $10 \mathrm{~mm}$ in diameter were used in specimens after polishing by sand paper.

The standard mixing procedure i.e., ASTM C 192 [13] was adopted for preparing concrete mix. The details of the mixing procedure for LWC are published elsewhere by author [7]. The test specimens of the current research were similar in size and dimension to the previous research [10-12], with necessary changings to make current research more reliable and accurate. Same like previous research, in the current research the phenomenon of macro-cell as illustrated in Figure 1, was intended to be investigated in LWC.

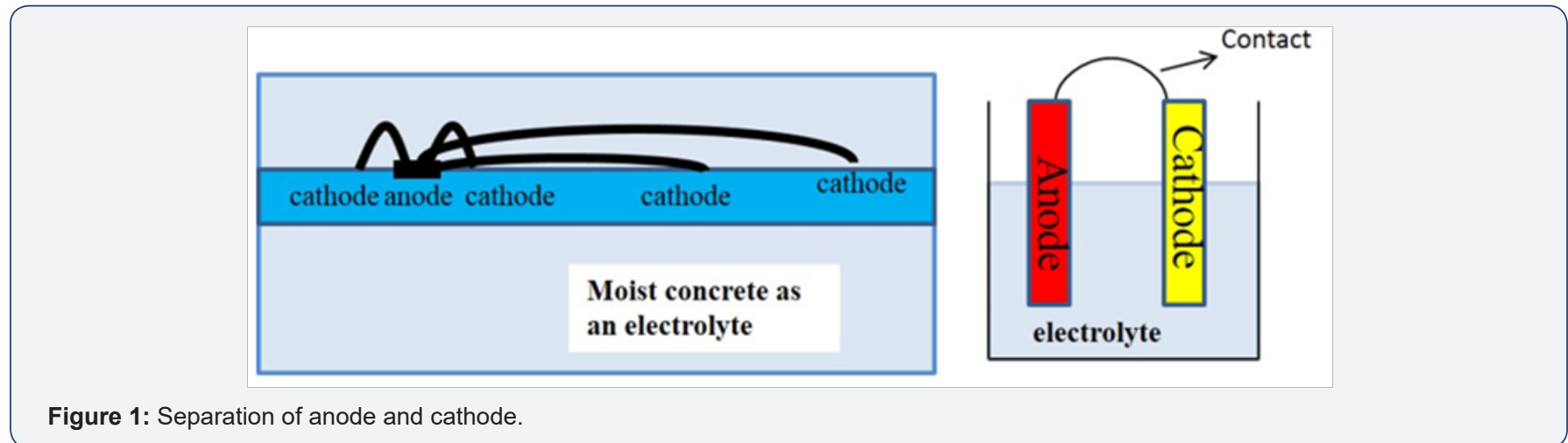

The schematic and the original photos of the specimens are shown in Figure 2. As can be seen in Figure 2 that for these specimens, the two sides were cast first containing $5 \%$ and $3 \%$ chloride content at the extreme ends respectively. The middle

\section{portion of these specimens was cast after one day with no \\ portion of these specinens was cast after one day with no}

admixed chloride to replicate the repaired portion in the field conditions so to prevent or minimize the further progress of corrosion. Further, details about the specimens' preparation can be obtained from authors published works [10-12].

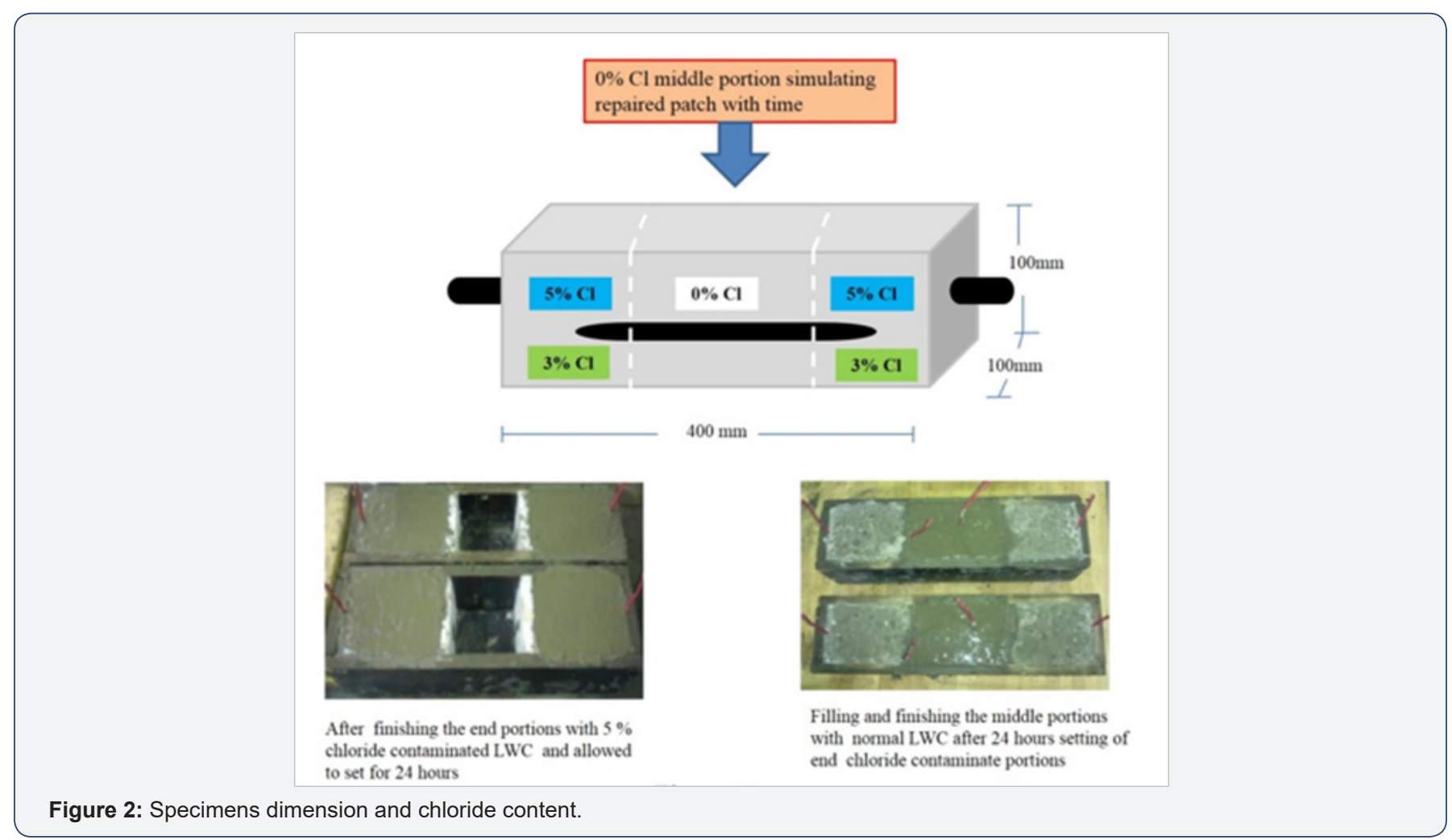




\section{Civil Engineering Research Journal}

The corrosion current (Icorr) and corrosion potential (Ecorr) were measured for all specimens using a GECOR device [14] and ASTM C-876 [15]. The GECOR measures the corrosion rate in terms of corrosion current density and the half-cell potential measurements. By linear polarization resistance Rp (k.ohms/ $\mathrm{cm}^{2}$ ), the corrosion current values are calculated in GECOR using the relation Icorr $\left(\mu \mathrm{A} / \mathrm{cm}^{2}\right)=\mathrm{B} / \mathrm{Rp}$, where $\mathrm{B}=26 \mathrm{mV}$. The Icorr is then correlated to corrosion rate $(\mu \mathrm{m} /$ year) by $11.6 \mathrm{x}$ Icorr $[7,10-12]$, hence, the reduction in rebar diameter due to corrosion over time is quantifiable. For, an electrochemical corrosion measurement such as corrosion rate an electrical signal is applied through a connection to the steel bar embedded in concrete. This signal is restricted to the rebar in a circle having diameter of $110 \mathrm{~mm}$ in GECOR. The GECOR device is a reliable and an accurate tool for the corrosion measurements as reported by many researchers including authors $[7,10-12,16]$. The schematic representation of the procedures involves in taking readings by GECOR is illustrated in Figure 3.

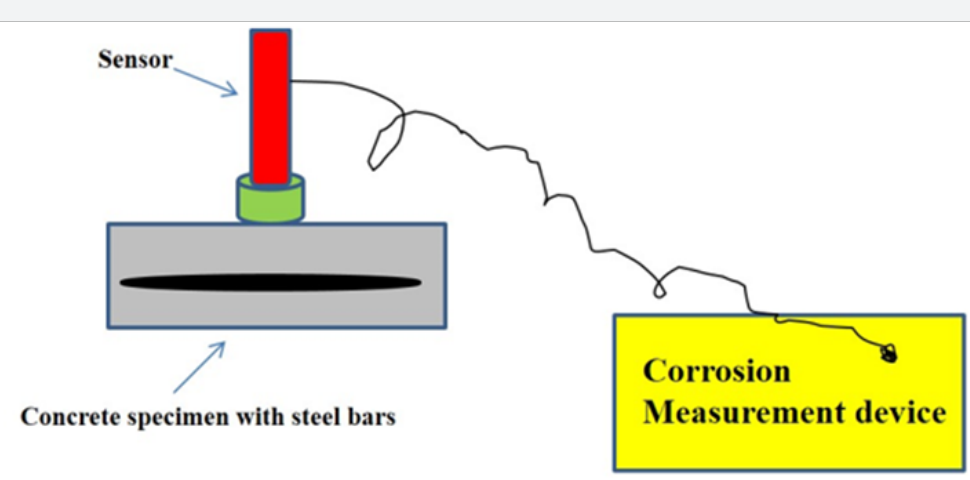

Figure 3: Corrosion current and corrosion potentials measurement assembly.

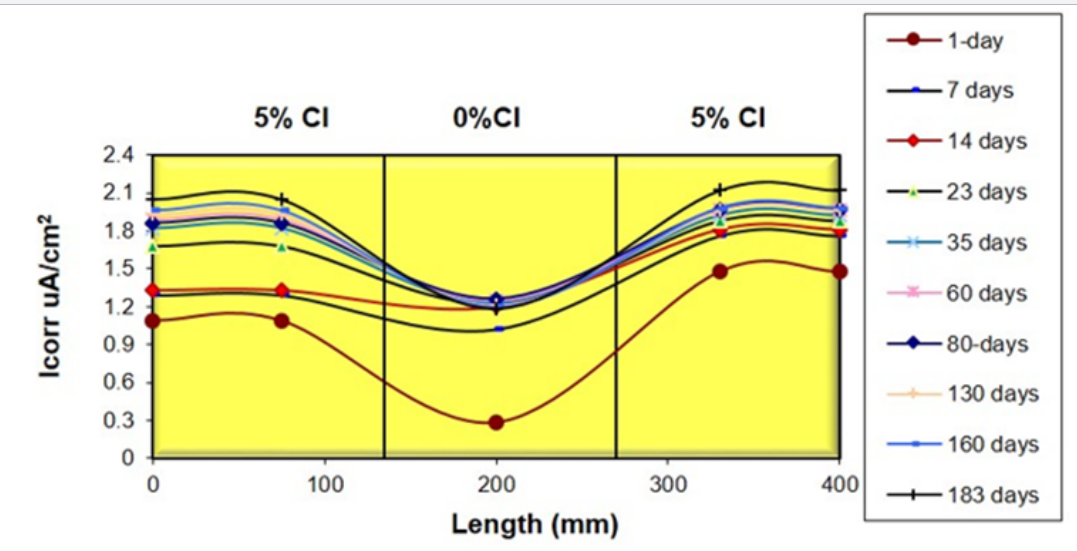

Figure 4: Corrosion current of $5 \%$ chloride contaminated LWC specimen at the two ends.

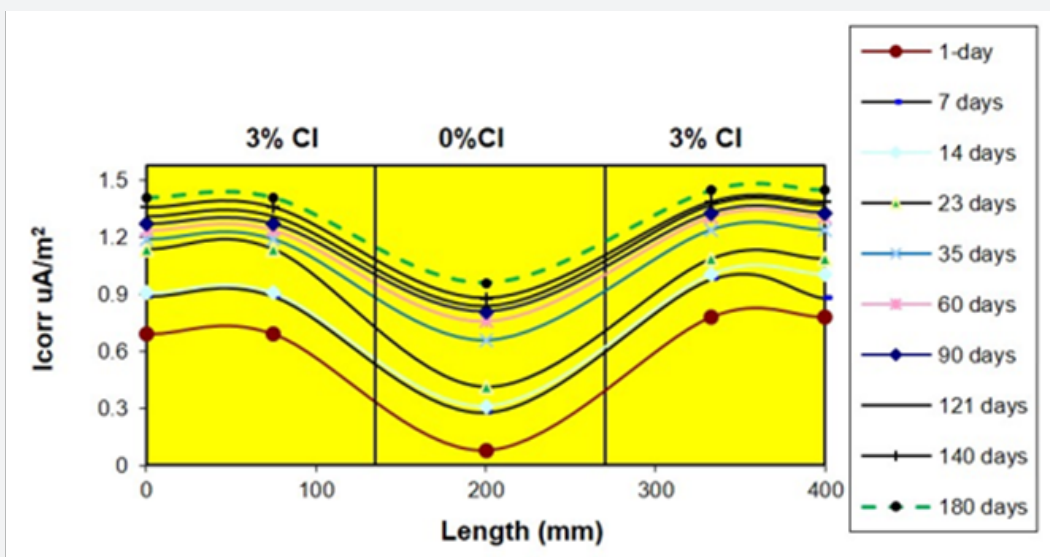

Figure 5: Corrosion current of $3 \%$ chloride contaminated LWC specimen at the two ends. 


\section{Civil Engineering Research Journal}

\section{Results and Discussion}

\section{Corrosion current}

Corrosion current (Icorr) is one of the reliable corrosion measurements; widely used for estimating corrosion of steel in concrete $[7,10-12,16]$. In the current research corrosion current readings were taken in accordance with standard procedures $[17,18]$. After six months of corrosion current observations; the following findings were observed.
In specimens (1 and 2) which were contaminated with 5\% chloride at the end portions, the highest corrosion current of $2.05 \mu \mathrm{A} / \mathrm{cm}^{2}$ was obtained after six months of observations while on day1, it was $1.09 \mu \mathrm{A} / \mathrm{cm}^{2}$ as shown in Figure 4 . This result indicates the rapid corrosion progress with time which probably could be due to the formation of macro-cell (anodic in nature) between contaminated and uncontaminated portions of the specimens.

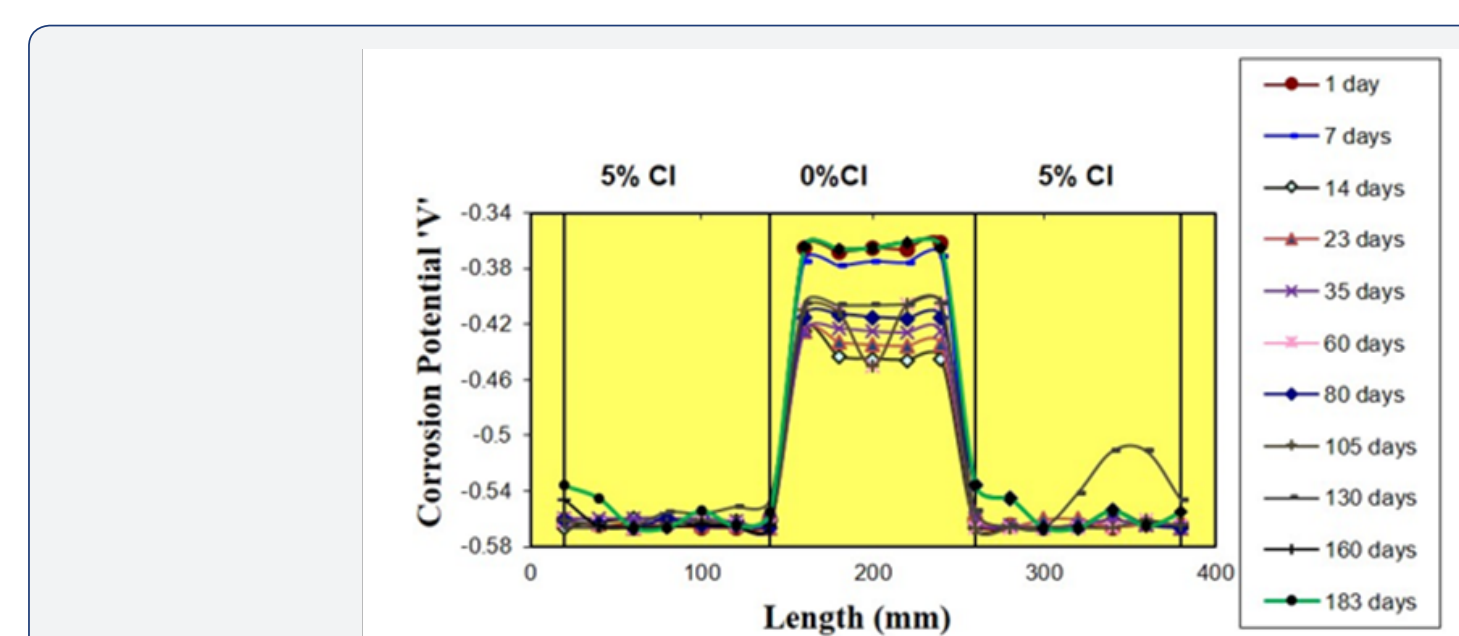

Figure 6: Corrosion potentials of $5 \%$ chloride contaminated LWC specimen at the two ends.

In order to observe the corrosion susceptibility of LWC and SCC construction for same exposure times, the obtained Icorr values were compared with the previous findings of the same SCC specimens [12]. Upon comparison, it was revealed that in SCC, the highest Icorr of $4.99 \mu \mathrm{A} / \mathrm{cm}^{2}$ was measured at the $60^{\text {th }}$ day, and then current started to decline. From this comparison, it can be inferred that initial corrosion rate in SCC is more than doubled as compared to LWC, suggesting more susceptibility to chloride attack and corrosion severity in initial days. Therefore, it can be said that LWC is more preferable if meeting the required design strength against the corrosion.

The middle $0 \%$ chloride portion of specimens 1 and 2 was also measured. Interestingly, the same corrosion progress with time was found in this uncontaminated portion. The highest corrosion current of $1.18 \mu \mathrm{A} / \mathrm{cm}^{2}$ was obtained after 6 months while on day1; it was $0.28 \mu \mathrm{A} / \mathrm{cm}^{2}$ as shown in Figure 6. The highest Icorr in $0 \% \mathrm{Cl}$ portion is found to be almost $58 \%$ of the highest corrosion obtained in the $5 \% \mathrm{Cl}$ contaminated end portions of this specimen, indicating the chloride transfer from contaminated portion to uncontaminated middle portion with time. Secondly, this result also suggests that the high Icorr (anodic) of $2.05 \mu \mathrm{A} / \mathrm{cm}^{2}$ at the two extreme ends induced a macro-cell (cathodic in nature) in the middle portion simulating patch repair.

The Icorr values of the middle portion of LWC (1 and 2) specimens were also compared with the same SSC specimens. It was found that in SCC specimens, the highest Icorr of $2.046 \mu \mathrm{A} /$ $\mathrm{cm}^{2}$ was obtained at the 60th day while on day1; it was $0.28 \mu \mathrm{A} /$ $\mathrm{cm}^{2}$ [12]. This comparison shows that even in the middle portion, the corrosion rates of SCC are double than the LWC specimens.

The specimens 3 and 4 of LWC which were $3 \% \mathrm{Cl}$ contaminated at the extreme end portion, the Icorr readings were also taken. The highest corrosion current of $1.41 \mu \mathrm{A} / \mathrm{cm}^{2}$ was obtained, while on day 1 , it was $0.78 \mu \mathrm{A} / \mathrm{cm}^{2}$, indicating the incremental increase in corrosion as shown in Figure 5. This result is exactly the same in trend as obtained in the $5 \% \mathrm{Cl}$ contaminated specimens, proving the originality of the corrosion phenomenon observed in the current research. From, the middle $0 \%$ chloride portion, the highest corrosion current of $0.96 \mu \mathrm{A} /$ $\mathrm{cm}^{2}$ was obtained while on day 1 it was $0.08 \mu \mathrm{A} / \mathrm{cm}^{2}$, showing the corrosion progress as shown in Figure 7. More interestingly, from the same 3 and 4 SCC specimens, the Icorr value of $2.93 \mu \mathrm{A} /$ $\mathrm{cm}^{2}$ in the contaminated and $1.313 \mu \mathrm{A} / \mathrm{cm}^{2}$ in the middle portion was obtained. These currents were again doubled than what obtained in $3 \% \mathrm{Cl}$ contaminated LWC specimens.

\section{Half cell-corrosion potentials}

The corrosion potentials readings of the LWC specimens were also taken for 180 days of corrosion using copper-copper sulfate reference electrode (CSE) in accordance with standard specifications ASTM C 876-09 to further corroborate the corrosion findings and measurements. The following results were obtained; 


\section{Civil Engineering Research Journal}

In specimens 1 and 2 which were $5 \% \mathrm{Cl}$ contaminated at the ends, the highest chloride induced corrosion potential of -0.565 Volts was found from the end portions. While, in the middle $0 \%$ chloride portion -0.445 Volts of cathodic potential was observed as shown in Figure 6. The reason behind this high -0.455 Volts potential at the middle $0 \% \mathrm{Cl}$ portion is already explained in the corrosion current measurements.
In $3 \%$ chloride contaminated specimens ( 3 and 4 ) at the end, the highest corrosion potential of $-0.355 \mathrm{~V}$ was obtained. While, it was found to be -0.255 Volt at the middle as shown in Figure 7 , indicating the same trend as obtained for $5 \%$ chloride contaminated specimens. These results confirm the formation of macro-cell even in the LWC.

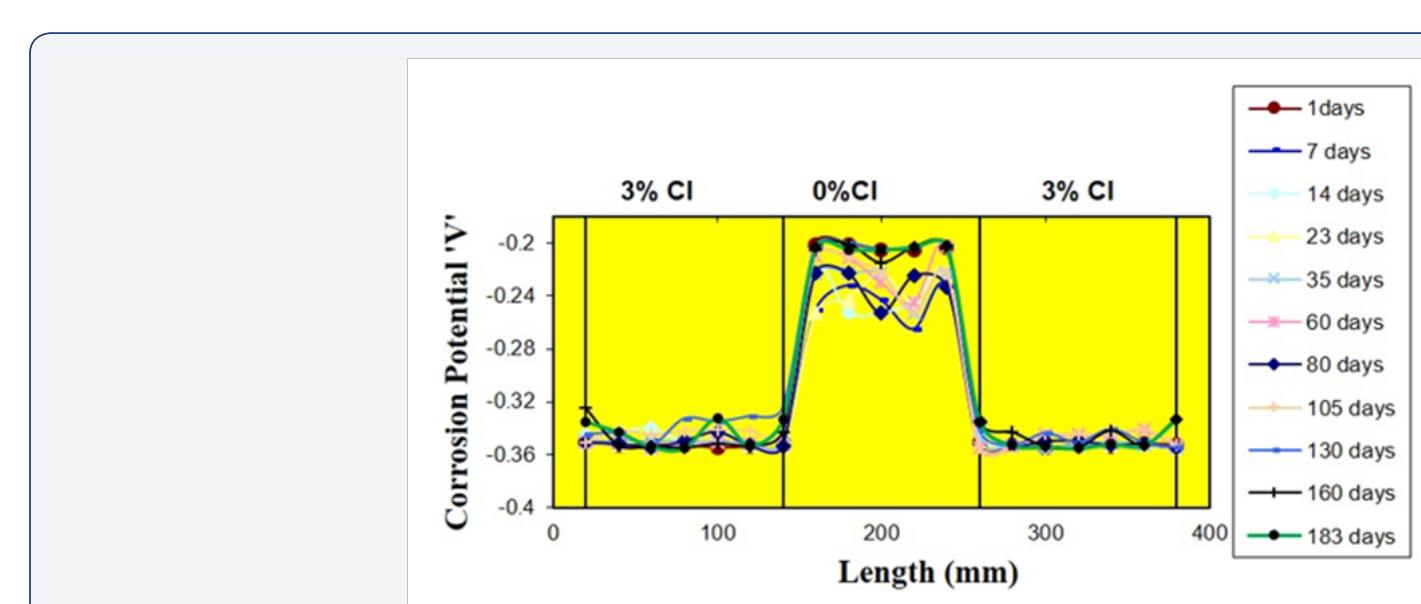

Figure 7: Corrosion potentials of $3 \%$ chloride contaminated LWC specimen at the two ends.

\section{Physical mass loss measurements}

After one six months of corrosion observations, the LWC specimens were split for conducting gravimetric mass loss measurements as per ASTM G1-90 [18]. The corroded steel bars taken out from $5 \%$ chloride contaminated specimens from the two ends and the middle portion are shown in Figure 8. From the mass loss measurements, the maximum percentage of $3.16 \%$ mass loss obtained from the steel in $5 \%$ contaminated portion of the LWC specimens, while the maximum of $2.36 \%$ mass loss of steel in the middle uncontaminated portion of these specimens was measured. These measurements clearly indicate the formation of macro-cell in the middle uncontaminated portion simulating repairs as very high corrosion mass loss obtained in the short span of six months. The results of percentage mass loss of different rebars of the specimens contaminated with $5 \% \mathrm{Cl}$ at the ends are plotted and shown in Figure 9. The mass loss measurements of the specimens contaminated with $3 \% \mathrm{Cl}$ at the ends were also performed. In these specimens the maximum of $2.21 \%$ mass loss was found from the steel in the end portions while maximum of $1.48 \%$ mass loss was obtained from the middle portion. These results further confirm the formation of macro-cell in the repaired patches of LWC.

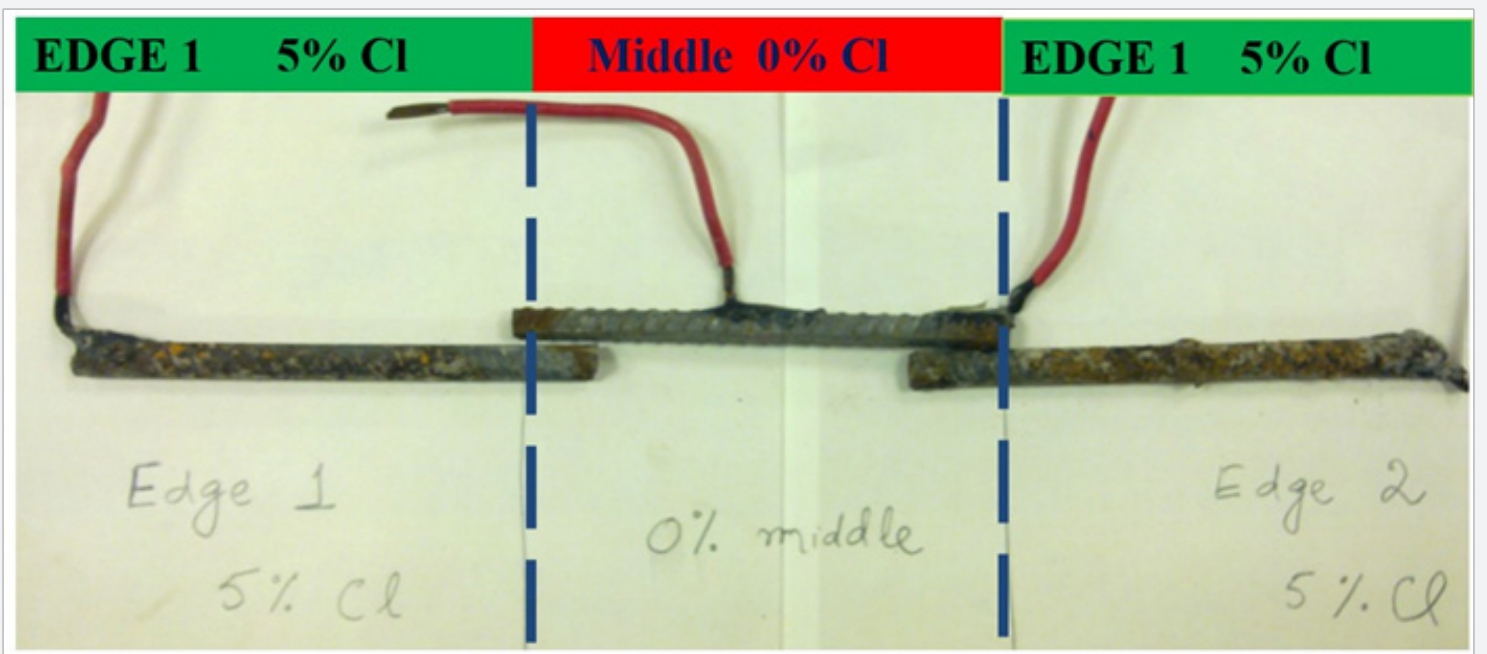

Figure 8: Visual observation of end and middle portion's steel bars of $5 \%$ contaminated specimen. 


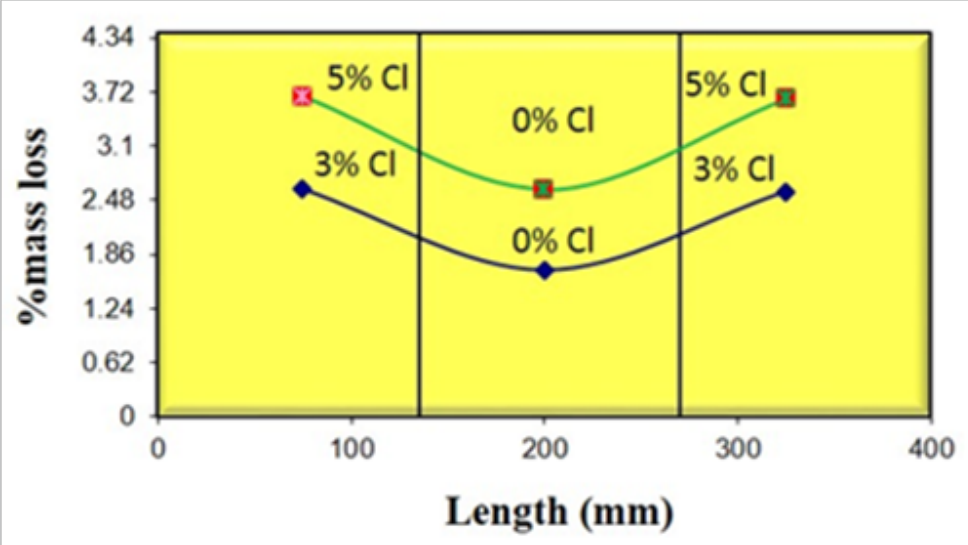

Figure 9: Percentage mass loss of end and middle portions of $5 \%$ and $3 \%$ contaminated specimens.

From the experimental findings of corrosion current and mass loss of the current research, it is evident that repaired corroded patches of LWC structures are susceptible to recorrosion in the form of macro-cell due to the chloride movement from the adjacent unrepaired corroded portions. Therefore, care must be given when performing such repairs on fields and the measures to prevent macro-cell corrosion should be developed to avoid further degradation of structures and infrastructures especially for those in chloride rich environments.

\section{Conclusion}

This paper presented the phenomenon of re-corrosion in the simulated repaired patches of corroded reinforced LWC in the highly corrosive conditions. From the test results, it is found that the at the two extreme ends of $5 \% \mathrm{Cl}$ contaminated LWC specimen, the highest Icorr and potential of $2.05 \mu \mathrm{A} / \mathrm{cm}^{2}$ and -0.565 Volts were obtained respectively. These highest corrosion values resulted in macro-cell cathodic corrosion current of $1.09 \mu \mathrm{A} / \mathrm{cm}^{2}$ and potential of -0.505 Volts in the simulated repaired portion of the same specimens. It is also found that in $3 \%$ chloride contaminated specimens; corrosion progressed to the uncontaminated simulated repaired portion of them causing unexpected high corrosion rates. In the lights of the results obtained in this research, it is vindicated that even repaired patches of the reinforced LWC against corrosion, can experienced more corrosion in the form of macro-cell from the surrounding unrepaired corroded areas due to chloride movements. The observations and results presented in this paper have practical applications and can be used in the prediction of the service life of corrosion affected LWC structures and for their maintenance strategies.

\section{References}

1. ACI Committee 213R (2014) Guide for Structural LightweightAggregate Concrete.

2. Owens PL (1999) Structural lightweight aggregate concrete-the future. Concrete (London) 33(10): 45-47.

3. Kayali O, Haque MN (2000) Status of structural lightweight concrete in Australia as the new millennium dawns. Concr Aust 25(4): 22-25.
4. Price B (1994) BP invests heavily in lightweight concrete for north sea. Concrete (London) 28(6): 9-13.

5. Mays GC, Barnes RA (1991) The Performance of lightweight aggregate concrete structures in service. Struct Eng 69(20): 351-361.

6. Dinelli G, Belz G, Majorana CE, Schrefler BA (1996) Experimental investigation on the use of fly ash for lightweight precast structural elements. Mater Struct 29(10): 632-638.

7. Wasim M, Hussain RR (2015) Passive film formation and corrosion initiation in light weight concrete structures as compared to selfcompacting and ordinary concrete structures at elevated temperature in chloride rich marine environment. Construct ion and Building Materials.

8. Kayali O, Haque MN, Zhu B (2003) Some characteristics of high strength fiber reinforced lightweight aggregate concrete Cem. Concr Compos 25(2): 207-213.

9. Wasim M, Hussain RR, Bloch MA (2014) Repair Vulnerability of Corrosion Patch Repairs at the Steel Intersection Areas of Reinforced Concrete Slabs Influenced by Harsh Weather. Industrial \& Engineering Chemistry Research. Ind Eng Chem.

10. Hussain RR, Wasim M, Ishida T (2010) Induced Macro-Cell Corrosion Phenomenon in the Simulated Repaired Reinforced Concrete Patch. Australian Journal of Civil Eng, Australia 8(1): 53-60.

11. Wasim M, Hussain RR (2012) Unique Declining Electrochemical Trend of Macro-Cell Half-Cell Potential with Increase in Temperature at Constant High Humidity for Corroding Steel Bars in Repaired Concrete Patches. Int J Electrochem Sci 7(2012): 1412-1423.

12. Wasim M, Hussain RR (2013) A Comparative Study on Induced Macrocell Corrosion phenomenon in Repaired Ordinary Reinforced and Self Compacting Concrete Structures. Corrosion Eng Sci and Tech, 370-379.

13.ASTM C192/C192M-07 (2007) Standard Practice for Making and Curing Concrete Test Specimens in the Laboratory, ASTM, USA.

14.GECOR-8 (2012) Advanced Rebar Corrosion Rate Determination System.

15. ASTM C876-09 (2009) Standard test method for corrosion potentials of uncoated reinforcing steel in concrete, American Society for Testing and Materials, USA.

16. Andrade C, Alonso C, Sarra J (2002) Corrosion Rate Evolution in Concrete Structures Exposed to the Atmosphere. Cement \& Concrete Composites 24(1): 55-64.

17. Hussain RR (2012) Time Dependent Electrochemical Effect of Saturated Area in Capillary and Gel Pores of Concrete on the Corrosion 


\section{Civil Engineering Research Journal}

Rate of Embedded Steel Reinforcement. Int J Electrochem Sci 7:14021411.

This work is licensed under Creative Commons Attribution 4.0 License DOI: 10.19080/CERJ.2018.06.555678
18. ASTM G1-90 (1999) Standard Practice for Preparing, Cleaning, and Evaluating Corrosion Test Specimens, ASTM International, $100 \mathrm{Barr}$ Harbor Drive, PO Box C700, West Conshohocken, PA, 19428-2959, USA

\section{Your next submission with Juniper Publishers} will reach you the below assets

- Quality Editorial service

- Swift Peer Review

- Reprints availability

- E-prints Service

- Manuscript Podcast for convenient understanding

- Global attainment for your research

- Manuscript accessibility in different formats

( Pdf, E-pub, Full Text, Audio)

- Unceasing customer service

Track the below URL for one-step submission https://juniperpublishers.com/online-submission.php 